\title{
Prevalence of migraine among university students at Parakou, Benin: A cross-sectional study
}

\author{
Thierry Adoukonou ${ }^{1,2}$, Francis Tognon-Tchegnonsi ${ }^{1}$, Kouna Philomène ${ }^{3}$, Abdias Alabi ${ }^{2}$, \\ Dismand Houinato $^{4,5}$, Pierre-Marie Preux ${ }^{5}$ \\ ${ }^{1}$ Unité d’Enseignement et de Recherche de Neurologie, Faculté de Médecine, Université de Parakou, Parakou, Benin \\ ${ }^{2}$ Unité de Neurologie du Service de Médecine Hôpital de Parakou, Parakou, Benin \\ ${ }^{3}$ Faculté de Médecine, Université des Sciences de la Santé de Libreville, Libreville, Gabon \\ ${ }^{4}$ Unité d’Enseignement et de Recherche de Neurologie, Faculté des Sciences de la Santé de Université d’Abomey-Calavi, Cotonou, \\ Benin. \\ ${ }^{5}$ Institut d’Epidémiologie Neurologique et de Neurologie Tropicale, Limoges, France \\ Email: adoukonouthierry@yahoo.fr
}

Received 5 November 2013; revised 5 December 2013; accepted 12 December 2013

Copyright (c) 2014 Thierry Adoukonou et al. This is an open access article distributed under the Creative Commons Attribution License, which permits unrestricted use, distribution, and reproduction in any medium, provided the original work is properly cited. In accordance of the Creative Commons Attribution License all Copyrights (c) 2014 are reserved for SCIRP and the owner of the intellectual property Thierry Adoukonou et al. All Copyright (C) 2014 are guarded by law and by SCIRP as a guardian.

\section{ABSTRACT}

Objective: To determine the prevalence of migraine and its associated factors in students at the University of Parakou. Methods: It was a cross-sectional study carried out from February 1st to April 30th 2011. It included all students registered during the academic year 2010-2011 and selected by systematic random sampling. Migraine was defined according to IHS 2004 criteria. To assess the link between migraine and body mass index we collected height and weight of each student. Multivariate analysis was used to study the factors associated with migraine, odds-ratio and their confidence interval were estimated. SPSS Soft-ware was used to perform statistical analysis. Results: During the study period 1200, students returned their questionnaires. They were 842 males and 358 females. 171 fulfilled migraine criteria, and the overall prevalence of migraine was $14.2 \%$ (CI $95 \%$ : $11.6 \%$ $17.4 \%)$. The main associated factors were the sex with an OR: 2.3 (CI 95\%: 1.6 - 3.2) and family history of headache with an OR: 1.6 (CI 95\%: 1.1 - 2.4). Migraine with aura was the frequent form (59.1\%) and visual aura the frequent form of aura. No association was found between migraine and body mass index but students with obesity had high risk of migraine with aura OR: 3.8 (CI 95\%: 1.5 - 9.7) compared with those with normal weight. The main triggering factors were sleeplessness $(\mathbf{9 0 . 1 \% )}$ ) and mental fatigue (85.4\%). Conclusion: The results suggest a high prevalence of migraine among students at Parakou Uni- versity and no association between obesity and migraine.

\section{KEYWORDS}

Migraine; Prevalence; Epidemiology; Students; Obesity

\section{INTRODUCTION}

Migraine is a common primary headache and has a significant impact on young people. Several data on epidemiology of migraine among young people and students are available in western countries [1-4]. In developing countries especially in Africa few data are available. The prevalence of migraine has been estimated to $19.8 \%$ among Nigerian students [5] and 33.8\% in Kenya [6]. In Benin its prevalence was $11.3 \%$ among students in Cotonou [7]. In this study the associated factors were female sex, single marital status and presence of family history. This study concerned only students registered in the Faculty of Health sciences. No specifically study has been conducted on migraine in the Parakou University in the North of Benin. Other studies conducted in various areas estimate the relationship between body mass index and migraine [8] showed contradictory results [9,10].

\section{Objective}

We aimed to assess the prevalence and the clinical features of migraine and the relation between migraine and body mass index among University students in Parakou, 
Benin.

\section{METHODS}

\subsection{Study Design}

This was a cross-sectional study including the students regularly registered in the Parakou University during the academic year 2010-2011.

\subsection{Setting}

This study was conducted on students attending all the faculties of Parakou University, located within the third administrative area of Benin. Parakou is the second University in Benin which is located some $420 \mathrm{~km}$ north of Cotonou, the economic capital. The city of Parakou has a total population of 150,000 people [11].

During the academic year 2010-2011 there were seven faculties at Parakou University: the Faculty of Médecine, the Faculty of agronomy, the Faculty of Law and political sciences, the Faculty of Economic Sciences, the University Institute of Technology, the School of Epidemiology, the Faculty of Arts and Human Sciences. It was 10,293 students regularly registered during the academic year 2010-2011.

Data were prospectively collected between $1^{\text {st }}$ April and 31 May 2011.

\subsection{Participants}

\subsubsection{Eligibility Criteria}

Students regularly registered at Parakou University during the academic year and who were selected after sampling and had given their oral consent to participate.

\subsubsection{Methods of Selection of Participants}

Students were selected using systematic random sampling proportionally to the number of students in each faculty. The calculated sample size was distributed among the Faculties, proportionally to the number of students registered in each of them, and a numbered list of students was established (Table 1).

To select our sample, a sampling interval has been worked out for each Faculty by dividing the number of students registered by the number of students to be selected from it. Then, using the Epitable software, we selected the first student and the following students by applying sampling interval.

\subsection{Variables}

The main variable (outcome) was the migraine (yes/no). Exposures variables were:

- socio-demographic information (age, sex, marital status)

- the faculty of the student,
Table 1. Total size, expected sample, and number of students in the final random sample by attended by faculty in the university, Parakou, Benin, 2011.

\begin{tabular}{ccc}
\hline & Total size & Sample \\
\hline Faculty of Médecine & 937 & 446 \\
Faculty of agronomy & 444 & 250 \\
UIT & 615 & 314 \\
School of epidemiology & 83 & 45 \\
High degree school & 280 & 145 \\
Total & 2359 & 1200 \\
\hline
\end{tabular}

UIT: University Institute of Technology.

- clinical characteristics (family history of headache, intensity, frequency, age of onset, triggering factors)

- Body mass index: we distinguished 4 groups according to World Health Organization [14]:

- $<18.5 \mathrm{~kg} / \mathrm{m}^{2}$ : underweight

- 18.5 to $24.9 \mathrm{Kg} / \mathrm{m}^{2}$ : normal

- 25 to $29.9 \mathrm{~kg} / \mathrm{m}^{2}$ : overweight

- $30 \mathrm{~kg} / \mathrm{m}^{2}$ and more: obesity

\section{Diagnostic Criteria}

Migraine diagnosis was based on the IHS criteria of 2004 [12]. It listed criteria of migraine with and without aura and was the same as that used in our previous study [7]. This questionnaire was first translated and back translated again in French by Beninese neurologists.

For each student, we collected the data concerning height and weight in the register of local clinic (those data are available for each student since before registration a clinical examination was done systematically and the weight and height were taken according the standard criteria) [13]. Then the body mass index (BMI) was calculated by dividing the weight (kilogram) by the square of the height (meter).

We have done a pilot study to ensure the validity of self-administration. We have compared the results of twenty self-administrated to other twenty face-to-face interviews and showed an excellent validity (sensitivity: 95\%, specificity: $95 \%$ ).

\subsection{Study Size}

The sample size was computed for an expected prevalence of $11.3 \%$ (prevalence of migraine in a previous study among students in Benin) [7] with a precision of $1.8 \%$ and a risk of $5 \%$ in a two-sided situation. The minimal number of students was 1187 .

\subsection{Statistical Methods}

It was performed by using Epi-Info 6.04C and Statistical 
Package for the Social Science (SPSS) version 16 software.

Usual descriptive analysis was used: means and standard deviations, frequencies and confidence intervals (CI). Chi-2 test and independent t-test of Student were used for comparison in bivariate analysis. To estimate the association between migraine and covariates, odds ratios and their CI at 95\% were estimated for categories of age, sex, family history of migraine, marital status, and category of BMI.

A logistic regression model by using descending step by step procedure has been established. We included in the initial model all the variables with a p-value less than 0.2 in bivariate.

The level of significance has been fixed to 0.05 .

\subsection{Ethical Considerations}

The study was authorized by the educational authorities and students were informed about the study and had given their oral consent before receiving the questionnaires. Those students younger ( $<18$ years) we requested also their parent's consent.

\section{RESULTS}

1200 students were self-interviewed and returned questionnaires. They aged from 16 years to 54 years with average age 22.3 years $( \pm 4.4$ years). They were 842 males (70.2\%) and 358 female (29.8\%). The BMI ranged from 13.9 to $44.6 \mathrm{~kg} / \mathrm{m}^{2}$ with average of $21.8 \mathrm{~kg} / \mathrm{m}^{2}$ $( \pm 3.1)$. Other characteristics of the sample are summarized in the first column on Table 2.
Among the 1200 students 1180 reported at least one headache attack $99.0 \%$ (95\% CI 98.3 to 99.5$)$ and 44 had chronic daily headache (3.7\%).

A total of 171 students fulfilled migraine criteria. The lifetime prevalence of migraine was 14.3\% (95\% CI 12.3\% to $16.4 \%)$. Of those 101 met criteria for aura with the frequency of $8.4 \%$.

The prevalence of migraine according to socio-demographic characteristics and BMI are summarized in Table 2 .

The associated conditions of migraine in multivariate analysis were shown in Table 3 .

The age of onset of headache ranged from 2 years to 25 years with the mean of 12.4 years $(+/-4.6$ years), the total average was 12 years. The main characteristics of the migraine are summarized on Table 4.

Among the 171 migraine sufferers only 65 (38.0\%) had seen a medical doctor for their headache.

\section{DISCUSSION}

This is the first study on migraine among students in Parakou University applying the IHS diagnostic criteria. It had the same methodological approach as the previous study in Cotonou [7]. We have used a standard questionnaire based on I H S criteria 2004 still used in other epidemiological surveys. The self-administration of questionnaire can introduced biases in responses. Students can overestimate their symptoms and sometimes misunderstand some parts of the questionnaires. However a self-administered questionnaire was used in various studies [7,15-18] and an pilot study showed a good agreement with interviews.

Tab le 2. Prevalence of migraine by sex, age, marital status, BMI, and family history of headache.

\begin{tabular}{|c|c|c|c|c|}
\hline & Sample N (\%) & Migraine N (\%) & Crude OR (95\% CI) & p value \\
\hline \multicolumn{5}{|l|}{ Age (years) } \\
\hline $16-19$ & $300(25.0)$ & $44(14.7)$ & 1 & \multirow{3}{*}{0.46} \\
\hline $20-29$ & 817 (68.1) & $119(14.6)$ & $0.99[0.7-1.4]$ & \\
\hline 30 and more & $83(6.9)$ & $8(9.6)$ & $0.62[0.3-1.4]$ & \\
\hline \multicolumn{5}{|l|}{ Sex } \\
\hline Males & $842(70.2)$ & $92(10.9)$ & 1 & \multirow[t]{2}{*}{0.00001} \\
\hline Females & 358 (29.8) & $79(22.1)$ & $2.3[1.7-3.2]$ & \\
\hline \multicolumn{5}{|l|}{ Marital status } \\
\hline Single & $1126(93.8)$ & $163(14.5)$ & 1 & \multirow[t]{2}{*}{0.20} \\
\hline Married/widowed & $74(6.2)$ & $8(10.8)$ & $0.7[0.3-1.5]$ & \\
\hline \multicolumn{5}{|c|}{ Family history of headaches } \\
\hline Unknown & $373(31.1)$ & $44(11.8)$ & $1.2[0.7-2.0]$ & \multirow[b]{2}{*}{0.003} \\
\hline Yes & $565(47.1)$ & $101(17.9)$ & $2.0[1.3-3.1]$ & \\
\hline \multicolumn{5}{|l|}{ BMI $\left(\mathrm{kg} / \mathrm{m}^{2}\right)$} \\
\hline$<18.5$ & $116(9.7)$ & $17(14.7)$ & 1 & \multirow{4}{*}{0.20} \\
\hline $18.5-24.9$ & $929(77.4)$ & $126(13.6)$ & $0.9[0.5-1.6]$ & \\
\hline $25-29.9$ & 130 (10.8) & $21(16.2)$ & $1.1[0.6-2.3]$ & \\
\hline 30 and more & $25(2.1)$ & $7(28.0)$ & $2.3[0.8-6.2]$ & \\
\hline
\end{tabular}

$\mathrm{CI}=$ confidence interval; $\mathrm{OR}=$ odds ratio. 
Table 3. Factors associated to migraine among students in Parakou in multivariate (after adjusted on the age), Benin, 2011.

\begin{tabular}{ccc}
\hline & OR (95\% CI) & p value \\
\hline Sex (female/male) & $2.3(1.6-3.2)$ & 0.00001 \\
Family history of headache (Yes/No) & $1.6(1.1-2.4)$ & 0.014 \\
\hline CI = confidence interval; OR = odds ratio. & &
\end{tabular}

Table 4. Main clinical characteristics of migraine in students in Parakou, Benin, 2011.

\begin{tabular}{|c|c|c|}
\hline Characteristics & Number & Percentage \\
\hline \multicolumn{3}{|l|}{ Intensity } \\
\hline Moderate & 66 & 38.6 \\
\hline Severe & 105 & 61.4 \\
\hline \multicolumn{3}{|l|}{ Duration (hours) } \\
\hline$<4$ & 47 & 27.5 \\
\hline $4-72$ & 107 & 62.6 \\
\hline$>72$ & 17 & 9.9 \\
\hline \multicolumn{3}{|l|}{ Frequency (per month) } \\
\hline $1-4$ & 110 & 64.3 \\
\hline $5-9$ & 24 & 14.0 \\
\hline$>10$ & 1 & 0.6 \\
\hline Unknown & 36 & 21.1 \\
\hline \multicolumn{3}{|l|}{ Types of migraine } \\
\hline - Migraine without aura & 70 & 40.9 \\
\hline - Migraine with aura & 101 & 59.1 \\
\hline \multicolumn{3}{|l|}{ Types of aura } \\
\hline - Visual aura & 45 & 26.3 \\
\hline - Sensitive aura & 30 & 17.5 \\
\hline - Aphasic & 29 & 16.9 \\
\hline - Motor aura & 28 & 16.4 \\
\hline \multicolumn{3}{|l|}{ Main triggering factors } \\
\hline - Sleeplessness & 154 & 90.1 \\
\hline - $\quad$ Mental fatigue & 146 & 85.4 \\
\hline - Anxiety & 117 & 68.4 \\
\hline - Noise & 115 & 67.3 \\
\hline - Physical fatigue & 106 & 62 \\
\hline - Exposure to sun & 103 & 60.2 \\
\hline
\end{tabular}

The prevalence of migraine in this study was $14.3 \%$. In our previous study among students at Cotonou the prevalence of migraine, by using the same methodological approach was $11.3 \%$ [7]. We believe that the difference could be explained by the number of faculties and the students' home schools. Indeed in Cotonou the students were all from the Faculty of Health Sciences, while in Parakou they were from different Faculties. However, we did not find any difference in prevalence according to the origin of the students. Ogunyemi [5] in 1984 had found a high prevalence in students of science faculty, while students in health sciences had a lower prevalence of headache. Compared to other studies in Benin we found a higher prevalence. Indeed it has been reported respectively $8.9 \%$ and $3.3 \%$ among workers in Cotonou [19] and in a rural community in central Benin in Abomey [20]. These differences could be explained by dif- ferences in population, educational attainment, healthy worker effect age of subjects included and the triggers for access in different studies. Several studies conducted in the general population have reported prevalence significantly lower than that observed among students of Parakou.

It was higher than the 9.6\% reported by Wahab et al. among students at Ambrose Alli University in Nigeria [17] and higher than another in the same country which reported $6.4 \%$ for 1-year prevalence of migraine [15]. But it was close to another study among university students in Nigeria with 16.7\% [5]. Other studies in Africa reported prevalence range from $6.4 \%$ to $33.8 \%$ among students by using IHS criteria $[5-7,17,18]$. The difference could be explained by the timeline estimation of prevalence, the cultural reasons, the triggering factors and the study method such as self-administration, face to face interview.

Several studies conducted among the students with fairly similar criteria (IHS 1988 or 2004) have reported figures ranging from $2.1 \%$ to over $50 \%$ (see Table 5).

We think that the variation of prevalence cannot be simply explained by the difference of race. Indeed several studies conducted among students in Africa and other developing countries have reported prevalence significantly higher than those reported in Western countries. We postulate that the low prevalence of migraine among blacks long considered a reality, might be a confounding factor and that the main element that can explain the differences in prevalence was rather the level of education.

Among students (university level) we have not seen significant difference between black and white according to the data from study on this population.

The female predominance was consistently reported by most authors and could be explained by hormonal factors [33]. However in a study conducted in rural community, the main associated factors of migraine were sex and family history of headache. Genetic consideration of transmission of migraine can explain this fact. Indeed several studies suggested and supported this hypothesis $[34,35]$. Compared with our first study among students in Cotonou, we didn't find marital status as associated despite the same proportion of married students in both samples.

The migraine with aura was the most frequent form of migraine. The same results were reported by Dent $e t$ al. in a rural community of Tanzania [36]. This can be explained by the misunderstanding of the questionnaire on aura and the self-administered method. Dent et al. explained this by the methodology of their survey in which the head of family reported symptoms of other members [36].

No difference was seen between prevalence of migraine according to the body mass index despite the high 
Table 5. Prevalence of migraine among students in various setting.

\begin{tabular}{|c|c|c|c|c|c|c|c|c|c|}
\hline \multirow{2}{*}{ Year } & \multirow{2}{*}{ Authors (reference) } & \multirow{2}{*}{ Country } & \multirow{2}{*}{$\begin{array}{l}\text { Migraine } \\
\text { definition }\end{array}$} & \multirow{2}{*}{ Timeline } & \multirow{2}{*}{ Population } & \multirow{2}{*}{$\begin{array}{c}\text { Age of } \\
\text { interviewees }\end{array}$} & \multicolumn{2}{|c|}{ Prevalence } & \multirow{2}{*}{$\begin{array}{c}\text { Overall } \\
\text { prevalence }\end{array}$} \\
\hline & & & & & & & $\mathbf{M}$ & $\mathbf{F}$ & \\
\hline 1984 & Ogunyemi [5] & Nigeria & AHC & Whole life & Students & All & 15.6 & 19.8 & 16.7 \\
\hline 1994 & Kryst et Scherl [3] & USA & IHS & 12-months & Students & $>20$ years & 4.5 & 9.8 & 8.5 \\
\hline 1994 & Monteiro et al. [4] & Portugal & IHS/AHC & - & Students & - & - & - & $6.1 / 6.9$ \\
\hline 1996 & Amayo et al. [6] & Kenya & IHS & - & Students & - & - & - & 33.8 \\
\hline 1996 & Sanvito et al. (21) & Brazil & IHS & 1-year & Students & $17-43$ & 28.3 & 54.4 & 40.2 \\
\hline 1996 & Mitsikotas et al. [22] & Greece & IHS & 6-months & Students & $22-27$ & 1.6 & 3.3 & 2.4 \\
\hline 1999 & Split et Neuman [2] & Poland & IHS & 1-year & Students & $15-19$ & 10.0 & 28.4 & 28.0 \\
\hline 2001 & Bigal et al. [23] & Brazil & IHS & 1-year & Students & $18-31$ & 8.9 & 78.1 & 25.0 \\
\hline 2001 & Deleu et al. [24] & Oman & IHS & Lifetime & Students & $18-26$ & 6.6 & 15.5 & 12.2 \\
\hline 2002 & Dzoljic et al. [25] & Yugoslavia & IHS (menstrual) & - & Students (female) & $18-28$ & - & 12.6 & 12.6 \\
\hline 2004 & Zencir et al. [26] & Turkey & IHS & - & Students & $11-18$ & 6.7 & 11.0 & 8.8 \\
\hline 2006 & Demirkirkan et al. [27] & Turkey & IHS & - & Students & $10-34$ & 8.9 & 14.0 & 12.4 \\
\hline 2006 & Karli et al. [28] & Turkey & IHS & - & Students & $12-17$ & - & - & 14.5 \\
\hline 2007 & Fendrich [1] & Germany & IHS & 3-months & Students & $12-15$ & 1.6 & 3.5 & 2.6 \\
\hline 2008 & Bicakci et al. [29] & Turkey & ID Migraine & Lifetime & Students & $17-31$ & 16.5 & 27.4 & 21.9 \\
\hline 2008 & Kurt et al. [30] & Turkey & IHS & Lifetime & Students & $17-38$ & 12.9 & 23.5 & 17.9 \\
\hline 2009 & Wahab et al. [17] & Nigeria & IHS & Lifetime & Students & - & 8.9 & 10.3 & 9.6 \\
\hline 2009 & Ojini et al. [15] & Nigeria & IHS & 1-year & Students & - & 3.2 & 10.9 & 6.4 \\
\hline 2009 & Adoukonou et al. [7] & Benin & IHS & Lifetime & Students & $>16$ & 6.8 & 18.3 & 11.3 \\
\hline 2010 & Ofovwe et ofili [18] & Nigeria & IHS & 1-year & Students & $11-18$ & 9.9 & 16.9 & 13.5 \\
\hline 2010 & Fuh et al. [31] & Taiwan & IHS & 3-months & Students & $13-15$ & - & - & 12.2 \\
\hline 2010 & Falavigni [32] & Brazil & IHS & - & Students & $<30$ years & - & - & 6.9 \\
\hline 2011 & Current study & Benin & IHS & Lifetime & Students & All & 10.9 & 22.1 & 14.2 \\
\hline
\end{tabular}

frequency among students with obesity (BMI $>30)$ and the tendency of high risk. The literature data on this were conflicting $[37,38]$. The recent study suggested that the association between body mass index and migraine may be J-shaped $[39,40]$. Other studies had found no association between BMI and migraine [40]. Other finding is the increasing risk among those with underweight despite insignificant association. It is similar to the result of the study of Bigal et al. [37] and confirms that the association of migraine and BMI may be J-shaped. We can explain the no association between migraine and BMI by the high frequency of migraine with aura in our sample compared to other studies on this association. The pathophysiology of the association is still unclear and the preliminary studies suggested the role of serotonin, pep- tides such as orexin, adiponectin and leptin [41].

In summary, the prevalence of migraine was higher than some others reported in our country and was associated to sex (female) and family history of headache. Our epidemiological survey does not support the link between body mass index and migraine.

\section{CONFLICT OF INTEREST}

All authors declare no conflict of interest regarding this article.

\section{REFERENCES}

[1] Fendrich, K., Vennemann, M. and Pfaffenrath, V. (2007) 
Headache prevalence among adolescents-The German DMKG headache study. Cephalalgia, 27, 347-354. http://dx.doi.org/10.1111/j.1468-2982.2007.01289.x

[2] Split, W. and Neuman, W. (1999) Epidemiology of migraine among students from randomly selected secondary schools in Lodz. Headache, 39, 494-501. http://dx.doi.org/10.1046/j.1526-4610.1999.3907494.x

[3] Kryst, S. and Scherl, E. (1994) Population-Based Survey of the Social and Personal Impact of Headache. Headache, 34, 344-350.

http://dx.doi.org/10.1111/j.1526-4610.1994.hed3406344.x

[4] Monteiro, J.M., Matos, E. and Calheiros, J.M. (1994) Headaches in medical school students. Neuroepidemiology, $13,103-107$. http://dx.doi.org/10.1159/000110366

[5] Ogunyemi, A.O. (1984) Prevalence of headache among Nigerian university students. Headache, 24,127-130.5.

[6] Amayo, E.O., Jowi, J.O. and Njeru, E.K. (1996) Migraine headaches in a group of medical students at Kenyatta National Hospital, Nairobi. East African Medical Journal, 73, 594-597.

[7] Adoukonou, T., Houinato, D., Kankouan, J., Makoutodé, M., Paraiso, M., Tehindrazanarivelo, A., Viader, F. and Preux, P.M. (2009) Migraine among university students at Cotonou (BENIN). Headache, 49, 488-493. http://dx.doi.org/10.1111/j.1526-4610.2009.01408.x

[8] Scher, A.I., Stewart, W.F., Ricci, J.A. and Lipton, R.B. (2003) Factors associated with the onset and remission of chronic daily headaches in a population-based study. Pain, 106, 81-89.

http://dx.doi.org/10.1016/S0304-3959(03)00293-8

[9] Mattson, P. (2007) Migraine headache and obesity in women aged 40-74 years: A population-based study. Cephalalgia, 27, 877-880.

http://dx.doi.org/10.1111/j.1468-2982.2007.01360.x

[10] Horev, A, Wirguin, L., Lantsberg, L. and Ifergane, G. (2005) A high incidence of migraine with aura among morbidly obese women. Headache, 45, 936-938. http://dx.doi.org/10.1111/j.1526-4610.2005.05162.x

[11] Institut National de la Statistique et de l'Analyse Economique. Recensement général de la population et de l’habitation, Bénin, Février 2002. Synthèse des résultats. Direction des Etudes Démographiques. Cotonou, Bénin, 2003,1-36.

[12] Headache Classification Committee of the International Headache Society. (2004) The international classification of headache disorders. Cephalalgia, 24, 9-160.

[13] Thorogood, M., Connor, M.D., Tollman, S., LewandoHundt G, Fowkes G and Marsh J. (2007) A cross-sectional study of vascular risk factors in a rural South African population: data from the Southern African Stroke Prevention Initiative (SASPI). BMC Public Health, 7, 110.

[14] World Health Organization (WHO). 2011Global strategy on diet, physical activity, and health: Obesity and overweight.

http://www.who.int/mediacentre/factsheets/fs311/en/inde x.html
[15] Ojini, F.I., Okubadejo, N.U. and Danesi, M.A. (2009) Prevalence and clinical characteristics of headache in medical students of the University of Lagos, Nigeria. Cephalalgia, 29, 472-477. http://dx.doi.org/10.1111/j.1468-2982.2008.01766.x

[16] Lipton, R.B., Dodick, D., Sadovsky, R., Kolodner, K., Endicott, J., Hettiarachchi, J. and Harrison, W. (2003) A self-administered screener for migraine I primary care. The ID migraine validation study. Neurology, 61, 375382. http://dx.doi.org/10.1111/j.1468-2982.2008.01766.x

[17] Wakab, K.W. and Ugheoke, A.J. (2009) Migraine: Prevalence and associated disability among Nigerian undergraduates. Canadian Journal of Neurological Sciences, 36, 216-221.

[18] Ofovwe, G.E. and Ofili, A.N. (2010) Prevalence and impact of headache and migraine among secondary school students in Nigeria. Headache, 50, 1570-1575. http://dx.doi.org/10.1111/j.1526-4610.2010.01776.x

[19] Adoukonou, T., Houinato, D., Adjien, C., Avodé, D.G. and Preux, P.M. (2009) Prévalence de la migraine dans une population de travailleurs à Cotonou au Bénin. African Journal of Neurological Sciences, 28, 16-23.

[20] Houinato, D., Adoukonou, T., Ntsiba, F., Adjien, C., Avodé, D.G. and Preux, P.M. (2010) Prevalence of migraine in rural community in South Benin. Cephalalgia, 30, 62-67.

[21] Sanvito, W.L., Monzillo, P.H., Peres, M.F., Fera, M.P., da Cruz Gouveia, D.A., Murachovsky, J., dos Santos Salomão, W.R. and de Almeida Leme, R.J. (1996) The epidemiology of migraine in medical students. Headache, 36, 316-319. http://dx.doi.org/10.1046/j.1526-4610.1996.3605316.x

[22] Mitsikostas, D., Gatzonis, S., Thomas, A., Kalfakis, N., Ilias, A. and Papageoergiou, C. (1996) An epidemiological study of headache among medical students in Athens. Headache, 36, 561-564. http://dx.doi.org/10.1046/j.1526-4610.1996.3609561.x

[23] Bigal, M.E., Bigal, J.M., Betti, M., Bordini, C.A. and Speciali, J.G. (2001) Evaluation of the impact of migraine and episodic tension-type headache on the quality of life and performance of a university student population. Headache, 41, 710-719.

http://dx.doi.org/10.1046/j.1526-4610.2001.041007710.x

[24] Deleu, D., Khan, M.A., Humaidan, H., Al Mantheri, Z. and Al Hashami, S. (2001) Prevalence and clinical characteristics of headache in medical students in Oman. Headache, 41, 798-804. http://dx.doi.org/10.1046/j.1526-4610.2001.01146.x

[25] Dzoljic, E., Sipetic, S., Vlajinac, H., et al. (2002) Prevalence of menstrually related migraine and nonmigraine primary headache in female students of Belgrade University. Headache, 42,185-193. http://dx.doi.org/10.1046/j.1526-4610.2002.02050.x

[26] Zencir, M., Ergin, H., Sahiner, T., et al. (2004) Epidemiology and symptomatology of migraine among school children: Denizli urban area in Turkey. Headache, 44, 780785. http://dx.doi.org/10.1111/j.1526-4610.2004.04145.x

[27] Demirkirkan, M.K., Ellidokuz, H. and Boluk, A. (2006) 
Prevalence and clinical characteristics of migraine in university students in Turkey. The Tohoku Journal of Experimental Medicine, 208, 87-92. http://dx.doi.org/10.1620/tjem.208.87

[28] Karli, N., Akiş, N., Zarifoğlu, M., Akgöz, S., Irgil, E., Ayvacioğlu, U., Calişir, N., Haran, N., and Akdoğan, O. (2006) Headache prevalence in adolescents aged 12 to 17: A student-based epidemiological study in Bursa. Headache, 46, 649-655.

http://dx.doi.org/10.1111/j.1526-4610.2006.00362.x

[29] Bicakci, S., Bozdemir, N., Over, F., Saatci, E. and Sarica, Y. (2008) Prevalence of migraine diagnosis using ID Migraine among university students in southern Turkey. The Journal of Headache and Pain, 9, 159-163. http://dx.doi.org/10.1007/s10194-008-0031-0

[30] Kurt, S. and Kaplan, Y. (2008) Epidemiological and clinical characteristics of headache in university students. Clinical Neurology and Neurosurgery, 110, 46-50. http://dx.doi.org/10.1016/j.clineuro.2007.09.001

[31] Fuh, J.L., Wang, S.J., Lu, S.R., Liao, Y.C., Chen, S.P. and Yang, C.Y. (2010) Headache disability among adolescents: a student population-based study. Headache, 50, 210-218. http://dx.doi.org/10.1111/j.1526-4610.2009.01531.x

[32] Falavigna, A, Teles, A.R., Velho, M.C., Vedana, V.M., Silva, R.C., Mazzocchin, T., Basso, M. and Braga, G.L. (2010) Prevalence and impact of headache in undergraduate students in Southern Brazil. Arq Neuropsiquiatr, 68, 873-877. http://dx.doi.org/10.1590/S0004-282X2010000600008

[33] Silberstein, S.D. (1992) The role of sex hormones in headache. Neurology, 42, 37-42.

[34] Ducros, A., Tournier-Lasserve, E. and Bousser, M.G. (2002) The genetics of migraine. Lancet Neurology, 1, 285-293.
http://dx.doi.org/10.1016/S1474-4422(02)00134-5

[35] Ducros, E., Denier, C., Joutel, A., Cecillon, M., Lescoat, C., Vahedi, K., Darcel, F., Vicaut, E., Bousser, M.-G. and Tournier-Lasserve, E. (2001) The clinical spectrum of familial hemiplegic associated with mutations in a neuronal calcium channel. The New England Journal of Medicine, $345,17-24$. http://dx.doi.org/10.1056/NEJM200107053450103

[36] Dent, W., Spiss, H.K., Helbok, R., Matuja, W.B.P., Scheunemann, S. and Schmutzhard, E. (2004) Prevalence of migraine in a rural area in South Tanzania: A door-to-door survey. Cephalalgia, 24, 960-966. http://dx.doi.org/10.1111/j.1468-2982.2004.00775.x

[37] Bigal, M.E., Liberman, J.N. and Lipton, R.B. (2006) Obesity and migraine: A population based study. Neurology, 66, 545-550. http://dx.doi.org/10.1212/01.wnl.0000197218.05284.82

[38] Peres, M.F., Lerario, D.D., Garrido, A.B. and Zukerman, E. (2005) Primary headaches in obese patients. Arquivos de Neuro-Psiquiatria, 63, 931-933. http://dx.doi.org/10.1590/S0004-282X2005000600005

[39] Bigal, M.E., Tsang, A., Loder, E., Serrano, D., Reed, M.L. and Lipton, R.B. (2007) Body mass index and episodic headaches: A population-based study. JAMA Internal Medicine, 167, 1964-1970. http://dx.doi.org/10.1001/archinte.167.18.1964

[40] Winter, A.C., Berger, K., Buring, J.E. and Kurth, T. (2008) Body mass index, migraine frequency and migraine features in women. Cephalalgia, 29, 269-278. http://dx.doi.org/10.1111/j.1468-2982.2008.01716.x

[41] Peterlin, B.L., Rapoport, A.M. and Kurth, T. (2010) Migraine and obesity: Epidemiology, mechanisms and implications. Headache, 50, 631-648. http://dx.doi.org/10.1111/j.1526-4610.2009.01554.x 